Print ISSN: 2053-4043(Print), Online ISSN: 2053-4051(Online)

\title{
THE MODERATING EFFECT OF CUSTOMER SATISFACTION ON THE LINK BETWEEN CUSTOMER RELATIONSHIP MANAGEMENT DIMENSIONS (CRMD) AND ORGANIZATIONAL PERFORMANCE IN TELECOMMUNICATIONS SECTOR IN SUDAN
}

\author{
Nuha Hassan Elmubasher Eltayib \\ Business and Economics College, Mashreq University \\ n.hassan.elmubasher@mashreq.edu.sd
}

\begin{abstract}
Purpose and Questions - This study serves not only to clarify the relationship between CRM dimensions and organizational performance, but also to explain the moderating role of customer satisfaction in this relationship to answer the following questions: What are the CRM dimensions in Sudanese telecommunications companies? To what extent is the CRM dimensions (customer orientation, CRM organization, knowledge management and technology based CRM) could affect organizational performance? Can customer satisfaction moderate the relationship between CRM dimensions (customer orientation, CRM organization, knowledge management and technology based CRM) and organizational performance? Design/methodology/approach - The data collection utilized a quantitative research method. The research questionnaires were distributed to 286 customers. Descriptive Statistics, factor analysis, ANOVA, multiple regression analysis and hierarchical multiple regression analysis were used to analyze the data collected. Findings - The result of this research showed that the implementation of CRM dimensions is more likely to improve organizational performance, when the company develops customer satisfaction. Research limitations/implications - The identification of CRM dimensions will help telecommunication managers to implement an effective customer relationship management (CRM) that enhances customer satisfaction and organizational performance. Originality/value - The findings of the study contribute enormously to the body of knowledge, as it provides a model to be used for explaining the moderating effect of customer satisfaction on the relationship between CRM four dimensions and organizational performance.
\end{abstract}

KEYWORDS: customer relationship management dimensions (CRMD), customer orientation, CRM organization, Knowledge management, Technology based, customer satisfaction, CRM organizational performance

\section{INTRODUCTION}

In the current business environment, customers are considered to be the central element of all marketing activities, among which CRM is a priority for firms marketing strategies (Karakostas et al., 2005). Academics and practitioners proclaimed that customer relations is necessary for firms to survive and be successful in contemporary business environment (Heinrich, 2005). Business firms are spending billions of dollars each year on CRM systems or applications (Haghshenas et al., 2015). Nowadays CRM gained importance as a popular business tool for a number of CRM projects if implemented successfully. Recently, Customers' needs organizational strategies and competition lead to essential change and development in marketing. In the past the main focus was on mass marketing and mass production, however, 
today 'customers' needs have changed rapidly and that led to change the processes of organizations" (Shafique et al., 2015, 28). The old concept of business that was product oriented model of "design-build-sell" was changed to new customer oriented model by "sellbuild-redesign" (Rygielski et al., 2002). Customer Relationship Management was a dual creation process in which information was captured, integrated, accessed then exchanged to create value for future customer from current customer (Boulding et al., 2005). Yim et al (2005) defined CRM dimensions as a collection of different activities (1) focusing on key customers, (2) organizing around CRM, (3) managing knowledge, and (4) incorporating CRM-based technology. Organizational performance is not only the outcome, it is a continuous process of different activities. There are three standard points and balance score were set as criteria to measure the organizational performance. First customer, second internal business process and third learning and growth of the organization (Kaplan and Norton, 1996).

\section{LITERATURE REVIEW}

\section{Customer Orientation:}

A customer-focused structure, culture, policy, and reward system should permeate any organization that strives to implement CRM successfully (Ryals and Knox, 2001). All interactions with key customers, who are often identified by "lifetime value computations," must fully reflect this company-wide CRM focus (Jain and Singh, 2002 and Schmid and Weber, 1998). The ultimate goal is to achieve deep customer relationships through which the seller organization becomes indispensable to its most profitable customers (Vandermerwe, 2004). Equipped with company-wide understanding and internal support for key customer relationships, the sales force generally is better enabled and motivated to cultivate long term customer relationships by offering more personalized products and services (Armstrong and Kotler, 2003).

\section{CRM Organization:}

With a strong focus on key customers deeply embedded throughout its CRM system, the entire company should be organized around cultivating these valuable relationships. The organizational structure needs to be flexible and, if necessary, reconstructed to generate customer-centric values (Homburg et al., 2000) and improve coordination of customerfocused, cross-functional teams (Brown, 2000 ; Homburg et al., 2000 and Sheth., 2002). For CRM success, there also must be an organization wide commitment of resources. With concerted efforts by all organizational functions to continuously provide a stream of value-rich actions and customer outcomes (Ahmed and Rafiq, 2003), the company and its sales force are assured that they can satisfy customers ${ }^{\text {ee }}$ needs and enhance customer relationships.

\section{Knowledge Management:}

Strongly related to knowledge management, successful CRM is predicated on effectively transforming customer information to customer knowledge (Freeland, 2003 and Peppard, 2000). Specifically, to enhance customer profitability, information about customers should be gathered through interactions or touch points across all functions or areas of the firm (Brohman et al., 2003), so that a 360-degree customer view is established, maintained, and continually updated (Fox and Stead, 2001). Customer knowledge thereby generated needs to be shared and disseminated throughout the organization (Peppard, 2000; Ryals and Knox, 2001) "to address customers $^{\text {ee }}$ current and anticipated needs. Salespeople are then equipped with a wealth of 
valuable customer knowledge to meticulously adjust marketing offers to fit the idiosyncratic needs of each customer" (Armstrong and Kotler, 2003).

\section{Technology Based CRM}

Many CRM-oriented activities, such as knowledge management, cannot be optimized without leveraging the latest technology. Indeed, most CRM applications take great advantage of technology innovations with their ability to collect and analyze data on customer patterns, develop prediction models, respond with timely and effective customized communications, and efficiently deliver personalized value offerings to individual customers (Peppard, 2000 and Vrechopoulos, 2004). With the development of sophisticated information management tools, such as database marketing, data warehousing, data mining, and push technology, companies are striving to seamlessly incorporate the latest technology into their CRM systems. In particular, salespeople frequently depend on continually updated software programs to better respond to their customers and build enduring customer relationships (Kotler, 2003). CRM technology helps companies and their sales people collect, analyze, and distribute information for enhanced prospecting, improved communication and sales presentations, and tailored product configurations. It also facilitates cross-referencing of customers within divisions of a company for greater sales opportunities (Widmier et al., 2002).

\section{Customers' Satisfaction:}

Satisfying products and services have the capacity to provide what is being sought to the point of being "enough". Two related words are satiation, which loosely means enough up to the point of excess, and satiety, which can mean a surfeit or too much of enough, as if to say that too much is necessarily undesirable. These terms illustrate the point that satisfaction implies a filling or fulfilment (Masroujeh, 2009). According to Kotler and Keller (2009) most companies pay more attention to their market share than to their customers ${ }^{\text {ee }}$ satisfaction, this is a mistake. Market share is a backward looking metric; customer satisfaction is a forward-looking metric. If customer satisfaction starts slipping, then market share erosion will soon follow. Kotler (2005) defined satisfaction as a person feeling of pleasure or disappointment resulting from comparing a product perceived performance or outcome in relation to his or her expectation.

Customer Satisfaction in Telecommunications Companies: Leelakulthanit and Hongcharn (2011) studied the determinants of customer satisfaction by interviewing 400 mobile phone users in Thailand. Their investigation found that promotional value, quality of customer service at shops and corporate image have a great impact on determining customer satisfaction. In addition, Khan and Uddinl (2010) interviewed 60 university students in Bangladesh who were also mobile users, to identify the determinant factors in selecting mobile service providers. Results of that study showed two factors, brand image and perceived call rate, to have the most impact on the consumers ${ }^{\text {ee }}$ selection decision of a mobile service provider in Bangladesh. Bugel et al (2010) studied the commitment to companies, in The Netherlands, using the psychological investment model. The study examined the customer-company relationships in five sectors: the banking industry, health insurance, supermarkets, mobile telecom providers, and the automotive industry. The study hired 300 respondents for each sector. With consider to satisfaction, the result of the study suggests that satisfaction plays an important role in determining customer commitment for service providers and there is a positive correlation between improving customer satisfaction and achievement customer loyalty. Sadia et al (2011) examined customer loyalty in the telecommunication industry in Pakistan, using 146 cell phone 
users. The study out comes was customer's loyalty is shaped mainly by: trust, service quality, staff loyalty, and switching cost. The results of this study agree, partially, with a study by Boohene and Agyapong (2011) of 460 clients of Vodafone telecommunications company in Ghana. This study concluded that satisfaction not always lead to loyalty, while service quality was found to be strongly and positively correlated with loyalty. However, it can be observed from the findings of this study that customer satisfaction is already built into service quality. Customers perceive service quality positively if they are satisfied with the service provider and with the services offered to them. The importance of service quality in the selection decision for a mobile provider was also considered by Rahman et al (2011) who conducted a study of 400 mobile telecom customers from major cities in Malaysia. This study concluded that network quality is one of the important factors in overall service quality. In addition to service quality, the study found that price plays an important role in the choice criteria for mobile telephone operators in Malaysia. The previous finding is not far from the result of a study conducted by Gupta and Sharma (2009) in India, They concluded that in order to retain customers and attract new customers, mobile service providers must provide service with reasonable quality without any hidden price, the two most important determinants of consumer satisfaction. Belaji (2009) reported that perceived quality is an important predictor of customer satisfaction, which ultimately results in trust, price tolerance and customer loyalty. Oyeniyi and Abiodun (2011) studied the influence of service quality on customer satisfaction by investigated 148 customers of major telecom companies in Nigeria. The result was the service quality has a positive impact on satisfaction and loyalty. Customer's judge service quality in mobile telecom industry by the following: due to the fact that telecom firms do not provide tangible products, their service quality is usually assessed by measure of the service provider's relationship with customers. Thus, telecom service management should pay attention to staff skill profession and offering fast and efficient services (Boohene and Agyapong, 2011). Numbers of studies found that satisfaction in telecom industry is determined by the following factors: voice call quality, wireless coverage, and the customer complaint process (Kim et al., 2004). Although, some companies failed to retain their customers without satisfying them, but in some situations customer satisfaction may lead to customer retention. According to Almossawi (2012) in telecommunication industry, customer retention determines the success and survival of mobile service providers. This might be due to fierce competition, the high cost of attracting new customers, and the similarity of services offered by the operators. In this respect, Wong (2010) conducted a remarkable study using a usage and payment records of 1403 Canadian post-paid mobile customers over 3 to 7 years of study period. Wong found that greater loyalty, thus retention, is observed in customers with optimal rate plans than those with non-optimal ones. This indicates that in order to reduce churn rates (i.e. loss of customers), mobile service providers must seek effective customer retention strategies.

\section{Organizational Performance and measurement:}

Organizational performance is one of the major elements of discussion in managerial researches and with no doubt, one of the key points for success evaluation in the business companies. Generally the organizational performance is the factor which helps the company to evaluate the level of their intended achievements. Among the concrete factors of profitability in the organizational performance asset, stockholders share, investment profitability and the profit of each unit of stock can be mentioned. Subjective factors mostly include norms which are determined based on the judgment of groups in the organization. (Haghshenas and Ahmadi, 2015).Measurement of organizational performance is complex and complicated (Venkatraman, 
1989), thus it can be assessed through all the efforts which are put together to achieve the business goals (Akal, 1992). One of the most important performance measurements is Key Performance Indicators (KPIs), which evaluate the success of an organization or of a particular activity in which it engages, according to Richard et al (2009) the purpose of dealing with Key Performance Indicators to highlight a change in the traditional philosophy of performance measurements was necessary due to the lack of correlation between long-established drivers for Network Management indicators and the current Telecommunications Industry's aggressive 'business focus'. The selection of indicators therefore depends on the types of problems being addressed. In the telecommunications sector, the problems to be addressed may include: (a) large unsatisfied demand for service and non-availability of next generation telecommunications services required by business and commerce; (b) poor quality of service; (c) poor financial performance and lack of financial resources and (d) lack of qualified manpower. Performance indicators should be used to monitor progress in first addressing and then resolving the various problems affecting the performance (Richard at al., 2009).According to Goni (2011) the performance of an organization, particularly those that provide utility services to consumers in most instances is narrowly measured using quantitative indicators such as the total market share of the firm and a qualitative measure of its ability to provide satisfactory services to consumer or client. Performance assessment criteria of this nature obviously, is silent on the various factors that actually work together to influence good performance or otherwise of the firm. Accessibility, Retainability and Integrity are indicates the qualitative measurements of KPIs; "Accessibility performance can be expressed by means of the following KPI: Call Block Probability (CBP): this metrics represents the probability that the network blocked. Whatever the problem causes the blocking event. Such KPI is interesting for the conversational and streaming classes while is usually not important for the others since the relevant connections are typically always on. The present metric can usually be evaluated at both media-gate way and control level. CBP can be easily mapped into the Grade of Service (GoS) except for the fact that the GoS is referred to single trunks while the CBP refers to a path. Retainability performance generally depends on transmission tolerances and on system performance in terms of reliability of propagation medium. Integrity performance is an indication of the degree to which a service is provided without excessive impairments, once detained. Actually, temporary inabilities could influence the service, avoiding reaching Quality of Service QoS agreement. Conversational and streaming services put limits on the maximum packet delay per connection in order to guarantee real time communications. In case of data traffic, an emerging application in Internet Protocol (IP), networks is multimedia data streaming, mainly due to the expansion of voice over IP, video conference and audio-video broad cast services. In these scenarios, since no reliable transport protocol is used, data packet loss ratio has to be considered. Instead, the overall time spent for transmitting a certain amount of data is no longer important being the application time sensitive. Furthermore data packet transfer delay variation has to be considered" (Randaccio, 2007). Performance is a multidimensional construct that cannot be adequately reflected in a single performance item (Mohammed et al., 2013). Studies on firms' performance have adopted various approaches to conceptualize and measure performance. This argument suggests that a compound measure of performance would reflect more exactly a firm's development, as opposed to a single qualitative or accounting-related performance measure. This study used the Key Performance Indicator (KPI) to measure organizational performance (Telecommunications Company) through customers; measures are concerned with what really matters to the customers (Mohammed et al., 2013).Wu and Hung (2007) found that financial figures alone cannot 
provide a full understanding of CRM's effect and findings; so, the total performance perspective should be employed in the assessment of CRM findings. Therefore, it is critical using KPI to evaluate the impact of CRM on organizational performance. To assess organizational performance financial and non-financial indicators were used in this study.

\section{Problem Statement}

Companies those think that the customer relationship management was only sale force or technological driven software leads fail to implement customer relationship management, Because they were not fully understand customer relationship management (Shafique et al., 2015), as a result of the limited studies at the field. In this study, researcher recognized this as "a knowledge gap"; not in the basic knowledge of CRM, but in the methods by which can evaluate and implement CRM. Telecommunications companies in Sudan may not be perfect in appliance of CRM, or there is a doubt about the effectiveness of CRM and its contribution to long term success, because awareness of the companies has been increased in using the technology as a competitive advantage. However, they are still not aware enough about the CRM and how to use this technology in the right way and how this technology will be a solution to organize their systems and sustain their relationships with their customers. This study aims to investigate the "Impact of CRM dimensions on organizational performance by Moderating role of customer satisfaction" to answer the following questions:

- To what extent is the CRM dimensions (customer orientation, CRM organization, knowledge management and technology based CRM) could affect organizational performance?

- Can customer satisfaction moderate the relationship between CRM dimensions (customer orientation, CRM organization, knowledge management and technology based CRM) and organizational performance?

\section{Research Objectives}

The main objective of the study is to investigate the relationship between CRM dimensions, organizational performance and customer satisfaction in telecommunications company in Sudan. Specifically, the study aims to:

- investigate the relationship between the dimensions of CRM (customer orientation, CRM organization, knowledge management and technology based CRM) and organizational Performance.

- to evaluate the moderating effect of customer satisfaction between CRM dimensions and organizational performance

\section{Significance of the Study}

The significance of this study it is expected to provide an insight into the research process in this new area of technological development in Sudan. Even though a lot of studies have been conducted in this area, but their limitation is obvious: they did not investigate the relationship between CRM dimensions, organizational performance and customer satisfaction. This thesis is unique in analyzing the relationship and fills the gap in the literature by focusing on the study of the factors of CRM dimensions that influence the organizational performance in Sudan, and how a telecommunication companies can benefit from this study to face critical organizational issues of adaptation, survival, and competence in the face of an increasingly changing environment. 


\section{Hypotheses development}

H1: There is positive significant statistical relationship between customer orientation and organizational performance. (Vandermerwe, 2004); (Armstrong \& Kotler, 2003); ( Mohammed \& Rashid, 2012); (Reimann et al., 2010)

$\mathrm{H} 2$ : There is positive significant statistical relationship between CRM organization and organizational performance. (Homburg at, al., 2000) ; (Brown 2000) ; (Ahmed \& Rafiq 2003)

H3: There is positive significant statistical relationship between Knowledge management and organizational performance. (Freeland, 2003); (Brohman et al., 2003) ; (Fox \& Stead, 2001) ; (Peppard 2000; Ryals \& Knox 2001) ; (Armstrong \& Kotler 2003)

H4: There is positive significant statistical relationship between Technology. (Peppard, 2000; Vrechopoulos, 2004) ; (Kotler, 2005) ; (Widmier at, al., 2002); (Butler, 2000)

H5: Customer satisfaction will have moderating effect between the Customer orientation and organizational performance. (Kim et al., 2008)

H6: Customer satisfaction will have moderating effect between the CRM organization and organizational performance. ( Sin et al 2005; Yim et al., 2005) (Yim et al., 2005) ; (Akrouch et al., 2011; Sin et al., 2005)

H7: Customer satisfaction will have moderating effect between the Knowledge management and organizational performance. (Brohman et al., 2003) ; (Plessis \& Boon, 2004; Stringfellow et al., 2004) ; (Abdulateef et al., 2010; Akroush et al., 2011; Sin et al., 2005; Yim et al., 2005) ; (Sigala, 2005)

H8: Customer satisfaction will have moderating effect between the Technology based CRM and organizational performance. (Kasim \& Minai, 2009) ; (Minghetti, 2003) ; (Abdullateef et al., 2010) ; (Roberts et al., 2005); (Roberts et al., 2005)

\section{Conceptual Model}

The proposed model of this study conceptualizes the relationship among CRM dimensions, Customer satisfaction and organizational performance. The relationship is based on the effect of CRM on the organizational performance in the access of customer satisfaction. Based on the review of the previous literature, the researcher constructed a model that illustrates the relationship between the variables in figure (1). The relationship is based on the effect of CRM on the organizational performance in the access of customer satisfaction; these three variables have been developed based on the relationship marketing theory and also based on previous studies (Das et al., 2009; Sin et al,. 2005; Wu and Lu, 2012). 
Figure 1 A Model reflecting the relationship between the study variables

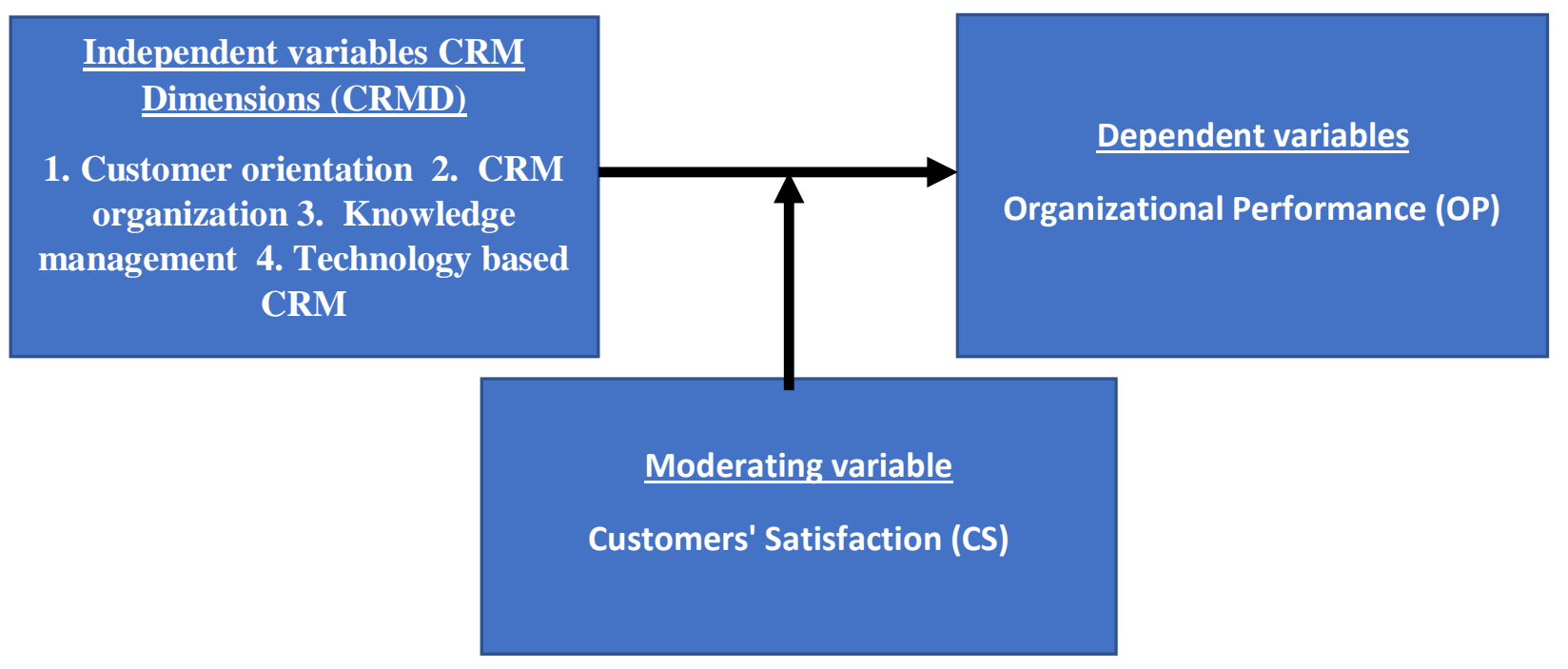

Source: Modeling Illustration based on reviewed literature.

\section{Research Variables}

The variables of this study are the Customer Relationship Management (dependent variable), Organizational Performance (independent variable) and Customer Satisfaction (a moderator variable). Independent variables CRM Dimensions (CRMD) 1. Customer orientation 2. CRM organization 3. Knowledge management 4. Technology based CRM.

Dependent variable According to (Bryman, 2008) dependent variable; a variable that is causally influenced by another variable (independent variable). In this study the dependent variable is organizational performance involve Accessibility, Retainability and Integrity (Randaccio, 2007).

Independent variables According to Simon et al., (1987), the independent variables are the variable force which is affected or adapted by some processes or experience. It may also symbolize the variable(s) you are trying to forecast. Occasionally the independent variable is called the research variable. In addition (Bryman, 2008) defined independent variable as a variable that has a causal impact on another variable (dependent variable). The independent variable is CRM involve four dimensions of CRM which include customer orientation, CRM organization, knowledge management, and technology based CRM (Abdullateef et al., 2010; Chang et al., 2010; Sin et al., 2005 and $\mathrm{Wu}$ and Li, 2011)

The Moderator variables Moderator variables are important, because specific factors are often assumed to reduce or enhance the influence that specific independent variables have on specific responses in question (dependent variable) (Baron and Kenny, 1986). In addition, the moderated relationship between two variables is said to be moderated when it holds for one category of a third variable but not for another category or other categories (Bryman, 2008). The moderator variable is Customer Satisfaction involve four dimensions which are Quality of services, Customers complains, Price and Overall satisfaction (Wang el al., 2004; Hansemark and Albinsson, 2004; Masroujeh, 2009; Hoffman and Bateson, 2011 and Leelakutthanit and Hongcharn, 2011). 


\section{METHODOLOGY}

The study adopted the exploratory and descriptive research type which is characterized by its flexibility. Purposive and convenient sampling methods were conducted in this study as a form of non-probability sampling in order to obtain a gross estimate of the results without wasting time, effort, and expense. 385 sets of questionnaires were distributed to the sample selected; however, only 286 (74\%) sets of questionnaires were successfully collected and completely answered. In testing the several hypotheses, multiple regression analysis and hierarchical regression analysis are used. Furthermore, it was imperative to apply statistical tools of analysis such as SPSS to ensure accuracy and consistency when expressing the results in quantitative form and when carrying out various analyses. After all the required data have been collected, the cleaning of these data will be undertaken in order to avoid any empty or missing data from the forms of data. Then the accepted data will be entered into a computer software package specially designed for statistical analysis called the Statistical Package for Social Science (SPSS). Indeed, many statistical techniques will be used in this stage to present the results from the quantitative analyses of data.

\section{Analysis and results}

\section{Respondents' General Information}

Table (1) revealed the following demographic information about the respondents: There were more male $(60.8 \%)$ than female $(39.2 \%)$. The ages of respondents are distributed across the following four bands: less than 30 years (43.4\%), 30-40 years (32.9\%) and 41-50 years (16.8\%) and above 51 years $(7.0 \%)$. The findings of this survey questionnaire in regards of Marital status found that most customers were Married (48.3\%), while (45.1\%) Single, $(4.5 \%)$ Divorced, and (2.1\%) are Widowed. According to the Income per month is distributed across three bands less than SDG1500 (39.2\%), SDG1500-2000 (25.9\%) and more than 2000 (35.0\%). In respect of the level of education most of the respondents had Bachelor degrees (62.9\%); whereas others had Master's degrees (11.5\%), Diplomas (18.9\%), PhDs (2.8\%) and secondary $(3.8 \%)$. The duration as costumers are distributed across three bands less than 5 Years $(31.5 \%)$, 5-10 Years $(35.7 \%)$, and 11 years and more (32.9\%). As regards of Occupation, the majority of them were Employee (58.4\%), followed by Student (23.8\%), Self-employed (15.0\%), Retired (1.7\%), Professional (3.0\%), and (7.0\%) are not working. According to the type of service used most of these customers are Pre paid (75.2\%), and (24.8\%) are post-paid.

Table (1): Respondents' General Information

\begin{tabular}{|c|c|c|c|}
\hline Category & Response & $\mathbf{N}$ & $\%$ \\
\hline \multirow[t]{2}{*}{ Gender } & Female & 112 & 39.2 \\
\hline & Male & 174 & 60.8 \\
\hline \multicolumn{2}{|l|}{ Total } & 286 & 100.0 \\
\hline \multirow[t]{4}{*}{ Age group } & $<30$ years & 124 & 43.4 \\
\hline & $30-40$ years & 94 & 32.9 \\
\hline & $41-50$ years & 48 & 16.8 \\
\hline & 51 years and above & 20 & 7.0 \\
\hline
\end{tabular}


British Journal Of Marketing Studies

Vol. 8, Issue 4, Pp.27-48, July, 2020

Published by ECRTD- $\boldsymbol{U K}$

Print ISSN: 2053-4043(Print), Online ISSN: 2053-4051(Online)

\begin{tabular}{|c|c|c|c|}
\hline \multicolumn{2}{|l|}{ Total } & \multirow{2}{*}{\begin{tabular}{|l|}
286 \\
54
\end{tabular}} & \multirow{2}{*}{$\begin{array}{l}\mathbf{1 0 0 . 0} \\
18.9 \\
\end{array}$} \\
\hline Educational level & Intermediate diploma & & \\
\hline & Bachelor & 180 & 62.9 \\
\hline & M. Sc. & 33 & 11.5 \\
\hline & Ph. D. & 8 & 2.8 \\
\hline & Secondary & 11 & 3.8 \\
\hline \multicolumn{2}{|l|}{ Total } & 286 & 100.0 \\
\hline \multirow[t]{4}{*}{ Marital status } & Single & 129 & 45.1 \\
\hline & Married & 138 & 48.3 \\
\hline & Divorced & 13 & 4.5 \\
\hline & Widowed & 6 & 2.1 \\
\hline \multicolumn{2}{|l|}{ Total } & 286 & 100.0 \\
\hline \multirow[t]{3}{*}{ Duration of costumers } & $<5$ years & 90 & 31.5 \\
\hline & 5-10 years & 102 & 35.7 \\
\hline & 11 years and more & 94 & 32.9 \\
\hline \multicolumn{2}{|l|}{ Total } & 286 & 100.0 \\
\hline \multirow[t]{2}{*}{ Type service used } & Pre-paid & 215 & 75.2 \\
\hline & Post paid & 71 & 24.8 \\
\hline \multicolumn{2}{|l|}{ Total } & 286 & 100.0 \\
\hline \multirow[t]{3}{*}{ Income per month (SDG) } & $<1500$ SDG & 112 & 39.2 \\
\hline & $1500-2000$ SDG & 74 & 25.9 \\
\hline & $>2000 \mathrm{SDG}$ & 100 & 35.0 \\
\hline \multicolumn{2}{|l|}{ Total } & 286 & 100.0 \\
\hline \multirow[t]{6}{*}{ Occupation } & Student & 68 & 23.8 \\
\hline & Employee & 167 & 58.4 \\
\hline & Retired & 5 & 1.7 \\
\hline & Self-employed, free business & 43 & 15.0 \\
\hline & Professional & 1 & 0.3 \\
\hline & Not working & 2 & 0.7 \\
\hline \multicolumn{2}{|l|}{ Total } & 286 & 100.0 \\
\hline
\end{tabular}

Source: researcher's data from questionnaire results 


\section{Reliability}

Reliability testing was performed to ensure that all areas of the constructs domain of interest were covered and that the items truly measured what they were supposed to measure before proceeding to undertake exploratory factor analysis (Sekeran, 2003). Therefore, it was highly pertinent to gauge the extent of reliability of the dependent variables, independent variable and moderator variables for all of items of the questionnaire, before proceeding to undertake exploratory factor analysis (EFA). The results of reliability testing are shown in Table 2. Below. The Cronbach's Alpha " $\alpha$ " value is greater than 0.7 for all factors except "Technology based CRM and Quality of services' which are close to 0.7, although, both are acceptable. A Cronbach's Alpha value of 0.7 or higher suggests good reliability and that the indicators of model variables validity are good (Hair et al., 2006).

Table 2. Reliability Measurement

\begin{tabular}{|c|c|c|c|}
\hline Dimension s & Variables & \begin{tabular}{|l} 
No. \\
of items
\end{tabular} & 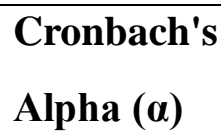 \\
\hline \multirow{4}{*}{ CRM Dimensions } & Customer Orientations & 4 & 0.70 \\
\hline & CRM Organization & 4 & 0.77 \\
\hline & Knowledge Management & 4 & 0.71 \\
\hline & Technology based CORM & 3 & 0.68 \\
\hline \multirow{4}{*}{$\begin{array}{l}\text { Customers } \\
\text { Satisfaction }\end{array}$} & Customers complains & 4 & 0.73 \\
\hline & Prices of products and services & 3 & 0.88 \\
\hline & Quality of services & 3 & 0.69 \\
\hline & Overall Satisfaction & 3 & 0.78 \\
\hline $\begin{array}{l}\text { Company } \\
\text { Performance }\end{array}$ & $\begin{array}{l}\text { Accessibility, Retainability } \\
\text { and Integrity }\end{array}$ & 8 & 0.71 \\
\hline
\end{tabular}

\section{Data Suitability}

\section{- Kaiser-Meyer-Olkin Test}

In general, the measure of sampling adequacy indicates whether or not the variables are able to be grouped into a smaller set of underlying factors, which should be greater than 0.5 for a satisfactory factor analysis to proceed. The results of this test (Table 3) show that the KMO measured between 0.670 and 0.820 . A KMO, value of $0.5-0.6$ indicates mediocre partial correlations, $0.6-0.7$ indicates moderate partial correlations, $0.7-0.8$ indicates good partial correlations, and $>0.08$ indicates excellent partial correlations or strong partial correlations are exhibited in the data for this study. This suggests that the data are suitable for EFA (Kaiser, 1974).

\section{- Bartlett's Test of Sphericity}


Bartlett's Test of Sphericity, the significance value is $\mathrm{p}<0.05$ (Bartlett, 1937). In the case of this study, all the Bartlett's Test of Sphericity values were significant, that is $p<0.05$, further confirming that these data are suitable for Factor Analysis (Table 3).

Table 3 KMO and Bartlett's Test

\begin{tabular}{|c|c|c|c|}
\hline Dimension s & Variables & KMO & $\begin{array}{c}\text { Bartlett's Test } \\
\text { of Sphericity }\end{array}$ \\
\hline \multirow{4}{*}{ CRM Dimensions } & Customer Orientations & 0.740 & 0.000 \\
\hline & CRM Organization & 0.670 & 0.000 \\
\hline & Knowledge Management & 0.820 & 0.000 \\
\hline & Technology based CRM & 0.720 & 0.000 \\
\hline \multirow{4}{*}{$\begin{array}{c}\text { Customers } \\
\text { Satisfaction }\end{array}$} & Customers complains & 0.730 & 0.000 \\
\hline & Prices of products and services & 0.710 & 0.000 \\
\hline & Quality of services & 0.680 & 0.000 \\
\hline & Overall Satisfaction & 0.720 & 0.000 \\
\hline $\begin{array}{c}\text { Company } \\
\text { Performance }\end{array}$ & $\begin{array}{c}\text { Accessibility, Retainability } \\
\text { and Integrity }\end{array}$ & 0.790 & 0.000 \\
\hline
\end{tabular}

Source: researcher's data from questionnaire results

\section{Validity}

Data will be useful and valid if it in fact measures what it needs to measure and, in this context, the idea of validity refers to the degree to which the data we gather give a correct measurement, or in other words, a description of ,social reality (what is ,,really happening ${ }^{\text {ee }}$ in society). In order to check the validity of variables we perform factor analysis to investigate the intercorrelation between variables. The validity of the measurement model was evaluated by checking content validity, convergent validity, and discriminant validity (Hair et al., 2006). Content validity was ensured by using measurement items validated by the research and pilot testing, which gives good confidence regarding the data survey. Confirmatory factor analysis was undertaken to check convergent validity and discriminant validity. Convergent validity was evaluated by examining composite reliability. For composite reliability, a threshold of 0.50 is considered to indicate the majority of the variance calculated for the construct, although values greater than .70 are considered more reliable. As shown in (Table 4), composite reliability values range from 0.8 to 0.9 . 
British Journal Of Marketing Studies

Vol. 8, Issue 4, Pp.27-48, July, 2020

Published by ECRTD- $\boldsymbol{U K}$

Print ISSN: 2053-4043(Print), Online ISSN: 2053-4051(Online)

Table 4: Composite Reliability

\begin{tabular}{|c|c|c|}
\hline \multirow{4}{*}{ Dimension s } & Variables & Composite Reliability \\
\hline \multirow{3}{*}{ CRM Dimensions } & Customer Orientations & 0.84 \\
\cline { 2 - 3 } & CRM Organization & 0.88 \\
\cline { 2 - 3 } & Knowledge Management & 0.84 \\
\cline { 2 - 3 } & Technology based CRM & 0.82 \\
\hline \multirow{3}{*}{$\begin{array}{c}\text { Customers } \\
\text { Satisfaction }\end{array}$} & Customers complains & 0.85 \\
\cline { 2 - 3 } & Prices of products and services & 0.94 \\
\cline { 2 - 3 } & Quality of services & 0.80 \\
\cline { 2 - 3 } & Overall Satisfaction & 0.88 \\
\hline Performance & Accessibility, Retainability and Integrity & 0.84 \\
\hline
\end{tabular}

Source: researcher's data from questionnaire results

\section{Hypothesis Testing}

In order to identify the relationship between all variables, (independent and dependent and moderator factors) multiple regression analysis and hierarchical multiple regression was used to carry out this task. The following section presents the hypotheses statements and the results of the findings. (Table 5) shows the variables and the items of the constructs used to test the model of hypotheses.

Table 5 Variables and Construct Items

\begin{tabular}{|c|c|c|}
\hline & Constructs & Items in analysis \\
\hline \multirow{4}{*}{ CRM Dimensions } & Customer Orientations & 4 \\
\hline & CRM Organization & 4 \\
\hline & Knowledge Management & 4 \\
\hline & Technology based CRM & 3 \\
\hline \multirow{4}{*}{$\begin{array}{l}\text { Customers } \\
\text { Satisfaction }\end{array}$} & Customers complains & 4 \\
\hline & Prices of products and services & 3 \\
\hline & Quality of services & 3 \\
\hline & Overall Satisfaction & 3 \\
\hline $\begin{array}{l}\text { Organizational } \\
\text { Performance }\end{array}$ & $\begin{array}{l}\text { Accessibility, Retainability } \\
\text { and Integrity }\end{array}$ & 8 \\
\hline
\end{tabular}

Source: researcher's data from questionnaire results 


\section{Multiple Regression Analysis}

Table (6) shows the results of multiple regression analysis between customer orientations, CRM organization, knowledge management, technology CRM and organizational performance. The adjusted squared multiple correlation coefficient (adjusted $\mathrm{R}^{2}$ ) clearly explains $30.1 \%$ of the variance associated with the organizational performance, (see Table 6). The F statistic is also significant $(F=15.228)$ (see also Table 6$)$, which confirms that not all the variables make a significant contribution to fit into regression model. Two independent variables, namely knowledge management and CRM organization, were found to be significantly associated with the organizational performance in Sudanese telecommunication companies in Sudan. As can be seen from Table (6), the organizational performance depends only on knowledge management and CRM organization. The term „Multicollinearity ${ }^{\text {ee }}$ has been coined to express the situation where the independent variables are higher associated with each other. The last column in (Table 6) shows that the highest VIF (Variance Inflation Factor) value is 1.365 , which is below 5 and therefore there is no problem of Multicollinearity (Hair et al., 2006). Thus the predictor variables can be considered to be independent from each other. As observed from Table (6), the most important variable was knowledge management, which had the highest Beta value of 0.302 and highest t-value of 4.136. This result shows a positive relationship between CRM (knowledge management) and organizational performance in Sudan. The result demonstrated the strongest correlation between these variables. Therefore, hypothesis 3 was substantiated. This finding is supported by (Freeland 2003; Yueh, et al., 2010; Mohammed and Rashid, 2012; Abdullateef, et al., 2010 and Elkordy, 2014) these studies indicates that Knowledge management have a positive influence on performance, because successful CRM is predicated on effectively transforming of customer information to customer knowledge and enhance customer profitability. The second most important variable associated with the perceived use of CRM in Sudan was CRM organization. The Beta value for this variable was .221 with t value of 3.799 . This result shows a positive relationship between CRM (CRM organization) and organizational performance. Therefore, hypothesis 2 was substantiated. This finding is supported by (Homburg at al., 2000; Brown, 2000 and Elkordy, 2014) all of these studies shows that CRM organization positively influences performance by focusing on the flexibility of the organizational structure to generate customer centric values, the company and its sales force are assured that they can satisfy customers' needs and enhance customer relationships. Accordingly, excellent CRM organization may lead to upgrade the organizational performance.

Table 6: The Results of Regression Model Analysis between Independent Variables and Dependent Variables.

\begin{tabular}{|c|c|c|c|c|c|c|}
\hline Variables & B & Std. Error & Beta & T & Sig. & VIF \\
\hline (Constant) & 1.910 & .178 & & 10.718 & .000 & \\
\hline customer orientations & -.051 & .048 & -.072 & -1.045 & .297 & 1.111 \\
\hline CRM org & .221 & .065 & .221 & 3.799 & $.000^{* *}$ & 1.037 \\
\hline knowledge mgt & .220 & .053 & .302 & 4.136 & $.000^{* *}$ & 1.249 \\
\hline technology CRM & .034 & .050 & .052 & .682 & .496 & 1.365 \\
\hline
\end{tabular}

Source: researcher's data from questionnaire results

Referring to Table (7), the p-value is less than 0.001; therefore usage depends on at least one of the predictors. The R-squared value is 0.301 , which means $30.1 \%$ of the variation in organizational performance can be explain by all 4 predictors. 
Table 7: ANOVA table 1

\begin{tabular}{|c|c|c|c|c|c|}
\hline Model & Sum of Squares & DF & Mean Square & F & Sig. \\
\hline Regression & 13.546 & 4 & 3.387 & 115.228 & $.000^{\mathrm{a}}$ \\
\hline Residual & 84.751 & 281 & .301 & & \\
\hline Total & 98.297 & 285 & & & \\
\hline $\mathrm{R}^{2}=0.301, \mathrm{~F}=15.228$ &
\end{tabular}

$\mathrm{R}^{2}=0.301, \mathrm{~F}=15.228$

Source: researcher's data from questionnaire results

Standard multiple regression can only accurately guess the relationship between dependent and independent variables if the relationships are linear in nature. Scatter plots are useful for showing relations between dependent and independent variables.

\section{- Hierarchical Regression Analysis}

To test the moderating effects of customer satisfaction in the relationship between CRM dimensions and organizational performance, this study use hierarchical multiple regression analysis suggested by Hayes's (2013) step. Table 5.38 provides the results of the hierarchical multiple regression analysis to access the effects of customer satisfaction. To test moderation analysis, this study particular be looking at the interaction effect between CRM dimensions and customer satisfaction and whether or not such an affect is significant in predicting organizational performance. The predictor variables were entered into the regression equation in the first step, this study accounted for $30 \%$ of the total variance in organizational performance. There was a significant increase in explained variance in the organizational performance ( $\mathrm{R}$ square change $=$ $0.50 ; \mathrm{p}<0.00)$ when the interaction variables were entered into the equation in the final step. In terms of the moderating influence of customer satisfaction between CRM dimensions and organizational performance, the effect of CRM dimensions on organizational performance is positively affect $(\beta=42.2$, sig. 0.000$)$. On other worlds customer satisfaction reflects the degree of change in the relationship between CRM dimensions and organizational performance, in this respect, customer satisfaction in this analysis was (.40), company can concentrate on customer satisfaction to increase the relationship between CRM and organizational performance, customer satisfaction have been shown to interact significantly with both variables, thus customer satisfaction moderate CRM and organizational performance. The most important variable was CRM organization, which had the highest Beta value of 0.335 and highest $t$-value of 5.718. This result shows that Customer satisfaction have moderated affect between CRM organization and organizational performance in Sudan. The result demonstrated the strongest correlation between these variables. Therefore, hypothesis 6 was substantiated. This finding supported by (Sin et al 2005; Yim et al., 2005 and Akrouch et al., 2011) these studies indicates the important of integrating the organization resources in order to implement CRM perfectly and as a result, to improve organizational performance, in addition, these studies indicates the positive affect of CRM organization on customer satisfaction. The second most important variable was knowledge management, which had the highest Beta value of 0.163 and highest t-value of 2.224. This result shows that Customer satisfaction have moderated effect between the knowledge management and organizational performance in Sudan. The result demonstrated the strongest correlation between these variables. Therefore, hypothesis 7 was substantiated. This finding supported by (Abdulateef et al., 2010; Akroush et al., 2011; Sin et al., 2005; Yim et al., 2005 and Sigala, 2005) these previous studies declared that managing knowledge effectively lead the organization to build a strong relationship with customers to enhance customer satisfaction and accordantly, resulting in a positive impact on organizational performance. The third important variable was 
customer orientation, which had Beta value of .222 and t-value of 2.223. This result shows that Customer satisfaction have moderated effect between the customer orientation and organizational performance in Sudan. The result demonstrated the strongest correlation between these variables. Therefore, hypothesis 5was substantiated. This finding supported by (Ko et al., 2008 and Elkordi, 2014) they studies states that good customer -oriented behaviours, in an organization, definitely ensures a tremendously positive impact on its performance. One of the important purposes of customer-oriented behaviours is to increase long-term satisfaction and to create customer loyalty. One of the important purposes of customer-oriented behaviours is to increase long-term satisfaction and to create customer loyalty. Studies have demonstrated that stronger customer-oriented behaviours in organizations have a positive impact on the organizations' performance. In short, the customer-orientation strategy is one of the organization's resources and a very important dimension of CRM. Therefore, organizations must have a customer-centric culture to implement CRM successfully and consequently create a competitive advantage. According to the previous discussion its can be observed that in the multiple regression analysis, the relationship between CRM dimensions and organizational performance was supported by only two dimensions namely; knowledge management and CRM organization, consequently, $\mathrm{H} 2$ and $\mathrm{H} 3$ were accepted while $\mathrm{H} 1$ and $\mathrm{H} 4$ were rejected. In addition, in the hierarchical multiple regression analysis, the moderating effect of customer satisfaction on the relationship between CRM dimensions and organizational performance was supported by three dimensions namely; CRM organization, knowledge CRM and customer orientation. Thus H5, H6 and H7 were supported while H8 was rejected. Based on these result it can be concluded that customer satisfaction moderate the relationship between CRM dimensions and organizational performance; the numbers of hypotheses supported increased from only two hypotheses to three hypotheses.

Table 8 Results of Hierarchical Regression Analysis - Testing the Interaction Effect of customer satisfaction against CRM dimensions on Organizational Performance

\begin{tabular}{|c|c|c|c|c|c|}
\hline \multirow[b]{2}{*}{ Model } & \multicolumn{2}{|c|}{ Unstandardized Coefficients } & \multirow{2}{*}{\begin{tabular}{|c|}
$\begin{array}{c}\text { Standardized } \\
\text { Coefficients }\end{array}$ \\
Beta \\
\end{tabular}} & \multirow[b]{2}{*}{$\mathbf{T}$} & \multirow[b]{2}{*}{ Sig. } \\
\hline & $\mathbf{B}$ & Std. Error & & & \\
\hline & 1.910 & .178 & & 10.718 & .000 \\
\hline \multicolumn{6}{|l|}{1 (Constant) } \\
\hline customer orientations & -.051 & .048 & -.072 & -1.045 & .297 \\
\hline CRM org & .221 & .065 & .221 & 3.799 & $.000 * *$ \\
\hline knowledge mgt & .220 & .053 & .302 & 4.136 & $.000 * *$ \\
\hline \multirow[t]{2}{*}{ technology CRM } & .034 & .050 & .052 & .682 & .496 \\
\hline & $R^{2}=.301$ & Adjusted $R^{2}=.35$ & $F=15.228$ & & \\
\hline 2 (Constant) & 1.806 & .170 & & 10.627 & .000 \\
\hline customer orientations & -.090 & .046 & .222 & 2.223 & $.043 * *$ \\
\hline CRM org & .335 & .050 & .335 & 5.718 & $.000 * *$ \\
\hline knowledge mgt & .119 & .053 & .163 & 2.224 & $.027 * *$ \\
\hline technology CRM & -.026 & .049 & -.040 & -.538 & .591 \\
\hline \multirow[t]{2}{*}{ customer satisfaction } & .317 & .056 & .422 & 5.698 & $.000 * *$ \\
\hline & $R^{2}=.50$ & Adjusted $R^{2}=.40$ & $F=39.473$ & & \\
\hline
\end{tabular}

Source: researcher's data from questionnaire results 
Table 8 confirms neither the first model CRM dimensions nor the second model CRM dimensions plus customer satisfaction predicted scores on the dependent variable to statistically significant degree look at the "sig" column for p-value which needs to be below 0.05 to be conceder as significant result. Both models are significant, thus customer satisfaction had an effect above and beyond the effects of CRM dimensions

Table 8 ANOVA table 2

\begin{tabular}{|c|c|c|c|c|c|}
\hline Model & Sum of Squares & Df & Mean Square & F & Sig. \\
\hline Regression & 13.546 & 4 & 3.387 & 15.228 & $.000^{\mathrm{a}}$ \\
Residual & 84.751 & 281 & .301 & & \\
Total & 98.297 & 285 & & & \\
\hline Regression & 22.354 & 5 & 4.471 & 39.473 & $.000^{\mathrm{b}}$ \\
Residual & 75.944 & 280 & .500 & & \\
Total & 98.297 & 285 & & & \\
\hline
\end{tabular}

Source: researcher's data from questionnaire results

\section{Hypotheses Results summary}

The purpose of this study is to understand the moderating effect of customer satisfaction on the relationship between CRM dimensions (customer orientations, CRM organization, knowledge management, technology CRM) and organizational performance.

H1: There is positive significant statistical relationship between Customer orientation and organizational performance. Customer orientation had no statistically significant effect on organizational performance, at Beta $=-.072, \mathrm{t}$ value $=-1.045$ and $\mathrm{Sig}=.297$ which is $>.05$ level for the craft category. Accordantly, these results show that customer orientation had no significant relationship with the organizational performance in telecommunications company Sudan.

H2: There is positive significant statistical relationship between CRM organization and organizational performance. The results of the correlations demonstrated the strongest correlation between CRM organization and organizational performance, the Beta $=.221, \mathrm{t}$ value $=3.799$ and $\mathrm{Sig}=.000$ which is $>.05$ level for the craft category, these results show a positive relationship between CRM organization and organizational performance in telecommunications company in Sudan.

H3: There is positive significant statistical relationship between knowledge management and organizational performance. The results of the correlations, demonstrated the strongest correlation between knowledge management and organizational performance, the Beta value for this variable was $.302, \mathrm{t}$ value was 4.136 and the sig was .000 which is $<.05$ level for the craft category. These results show a positive relationship between knowledge management and organizational performance in telecommunications company in Sudan.

H4: There is positive significant statistical relationship between technology based CRM and organizational performance. Technology based CRM had no statistically significant effect on organizational performance, at Beta $=.052$, $\mathrm{t}$ value $=.682$ and $\mathrm{Sig}=.496$ which is $>.05$ level for the craft category. Accordantly, these results show that technology based CRM had no significant relationship with the organizational performance in telecommunications company in Sudan. 
H5: Customer satisfaction will have moderating effect between the Customer orientation and organizational performance. The results of the correlations demonstrated that the increasing in customer satisfaction will affect the relationship between customer orientation and organizational performance, the Beta value for this variable was .222, $t$ value was 2.223 and the sig was .043 which is <.05 level for the craft category. These results show that a customer satisfaction had a moderating affect between the Customer orientation and organizational performance in telecommunications company in Sudan.

H6: Customer satisfaction will have moderating effect between the CRM organization and organizational performance. The results of the correlations, demonstrated that the increasing in customer satisfaction will affect the relationship between CRM organization and organizational performance, the Beta value for this variable was .335, $\mathrm{t}$ value was 5.718 and the sig was .000 which is $<.05$ level for the craft category. These results show that a customer satisfaction had a moderating affect between the Customer orientation and organizational performance in telecommunications company in Sudan.

H7: Customer satisfaction will have moderating effect between the Knowledge management and organizational performance. The results of the correlations demonstrated that the increasing in customer satisfaction will affect the relationship between knowledge management and organizational performance, the Beta value for this variable was .163, $t$ value was 2.224 and the sig was .027 which is $<.05$ level for the craft category. These results show that a customer satisfaction had a moderating affect between the knowledge management and organizational performance in telecommunications company in Sudan.

H8: Customer satisfaction will have moderating effect between the Technology based CRM and organizational performance. Customer satisfaction had no statistically significant effect on the relationship between Technology based CRM and organizational performance, at Beta $=-.040$, $\mathrm{t}$ value $=-.538$ and $\mathrm{Sig}=.591$ which is $<.05$ level for the craft category. Accordingly, these results show that a customer satisfaction had no moderating effect between the CRM organization and organizational performance in Telecommunications Company in Sudan.

\section{CONCLUSIONS}

The study was conducted by using quantitative and provided a better result for determining the best way for telecommunications companies in Sudan to adopt CRM. Adoption of CRM will enhance the companies to moves toward customer centricity. However, in order to have a highly effective CRM system, a company must be equipped with all four key success dimensions; customer orientation, CRM organization, knowledge management and technology base CRM. The implementation of effective CRM can result in efficiency and improvement, increase income and lead to better productivity. This study has provided a theoretical model to show the firm relationship between CRM dimensions, customer satisfaction and organizational performance. It provides a comprehensive framework that is used for explaining the impact of the CRM four dimensions on organizational performance. It is an accepted fact that the concept of CRM neither has been fully verified, nor empirically assessed to determine the strength of the relationship between dimensions of CRM and telecommunication sector performance. Moreover, this study uniquely extends the body of knowledge by explaining the theoretical possibilities of the moderating role of customer satisfaction in the relationship between CRM dimensions and organizational performance. It is worth mentioning that this paper will also raise awareness among managers to pay more attention to CRM dimensions, customer satisfaction and assist them in improving organizational performance and competitiveness. In addition, this 
study adds a further dimension to the literature in the knowledge base field. Moreover, the information on CRM gained from this research study will help companies establish an effective knowledge base policy and will also have wider implications for staff, companies, and society. It is hoped that the study results will be able to support all telecommunications managers to facilitate their CRM implementation process in order to improve and enhance their organizational performance. This study provides important insights into the enabling environment required for the successful implementation of CRM in telecommunication companies in Sudan. Furthermore, the findings are of particular importance to managers who are responsible for developing and implementing strategies. These findings will help corporations understand the effectiveness of relational exchange from the firm's perspective, and develop appropriate relationship marketing strategies accordingly. The instrument used in this research is available for management to measure their relationship CRM activities and organizational performance. providers should put their efforts into offering price reduction, customized services and free consultancy also they should meet deadline and estimated costs to be sure of having satisfied customers and they should put their efforts into reducing the number of complaints and handling properly those that will occur complain rather than improving service quality to obtain market performance. Customers are playing the most important role in company's success. This statement is the heart of marketing thinking and drives research into relationship marketing. In Sudan the marketing concept didn't always dominate organizational thinking. Indeed many firms emphasis on organizational efficiency and the use of relationship marketing strategies to persuade. CRM provides us with a short cut to formalize our relationship with the customers we serve rather than standing above these markets.

\section{Recommendations}

1. The approach used in this study could be extended to other companies and countries as an area of further research.

2. Any company in the world to occupy an eminent position in the global market place, it must build capacity for CRM development and employ a variety of techniques to satisfy customers.

3. It is recommended that the telecommunication company's must develop a Customer Complaints Structure CCS in order to deal and response to customer's complaints, and ensure that the customer requests are being taking care of in an efficient manner and proper response timing.

4. The updated information should include customer address, payment record from each subscription, their names, cell phone numbers, Emails and if possible dates of their special occasions. Such information will help the company to establish a proper contact with the customers at the proper time.

5. After the adoption of CRM concept, criteria of success measurements should be clearly illustrated in order to evaluate the performance, drive and monitor the success and set the proper plans for future development. 


\section{References}

Abdullateef, A. O., Mokhtar, S. S., \& Yusoff, R. Z. (2010). The impact of CRM dimensions on call center performance. International Journal of Computer Science and Network Security, 10(12), 184-195.

Ahmed, Pervaiz K., \& Mohammed Rafiq. (2003). Internal marketing issues and challenges. European Journal of Marketing, 37 (9), 1177-1186.

Almossawi, M. M. (2012). Customer satisfaction in the mobile telecom industry in Bahrain: Antecedents and consequences. International Journal of Marketing Studies, 4(6), 139.

Armstrong, G. \& Kotler,P. (2003). Marketing: an introduction. Upper Saddle River, NJ: Prentice Hall.

Balaji, M. (2009). Customer satisfaction with Indian mobile services. The IUP Journal of Management research, 8(10), 79-93.

Boohene, R., \& Agyapong, G. (2011). Analysis of the antecedents of customer loyalty of telecommunication industry in Ghana: The case of Vodafone (Ghana). International Business Research, 4(1), 229-

Boohene, R., \& Agyapong, G. (2011). Analysis of the antecedents of customer loyalty of telecommunication industry in Ghana: The case of Vodafone (Ghana). International Business Research, 4(1), 229-

Boulding, W., Staelin, R., Ehret, M., \& Johnston, W. J. (2005). A customer relationship management roadmap: what was known, potential pitfalls, and where to go. Journal of Marketing, 69(4), 155- 166.

Brohman, M.K., Richard T. Watson, Gabriele Piccoli, \& A. Parasuraman. (2003). Data completeness: a key to effective net-based customer service systems. Communications of the ACM, 46 (6), 47-51.

Brown, Stanley A. (2000). Customer relationship management: a strategic imperative in the world of E-Business. Canada: John Wiley \& Sons.

Bugel, M., Buunk, A., \& Verhoef, P. (2010). A comparison of customer commitment in five sectors using the psychological investment model.

ElKordy, M. (2014). The impact of CRM capability dimensions on organizational performance. European Journal of Business and Social Sciences, 2(10), 128-146.

Fox, T, \& Stead, S. (2001). Customer relationship management: delivering the benefits. A White Paper, CRM (UK) Ltd. and Secor Consulting Ltd, 14.

Freeland, J (2003). The new CRM imperative. the ultimate CRM handbook 1, NewYork, NY: McGraw Hill.

Freeland, J (2003). The new CRM imperative. the ultimate CRM handbook 1, NewYork, NY: McGraw Hill.

Goni, A, A. (2011). Assessing the operational performance of vodafone Ghana company limited in the Ganaian telecommunication industry. Master Thesis, Kwame Nkrumah University of Science and Technology, Ghana.

Gupta, D., \& Sharma, A. (2009). Customer loyalty and approach of service providers: An empirical study of mobile airtime industry in India. Services Marketing Quarterly, 30(4), $342-364$.

Haghshenas, M., \& Ahmadi, S. M. (2015). The effects of customer relationship management dimensions on organizational performance (Case study: shipping organization of Iran). WALIA journal, 31(4), 134-141. 
Haghshenas, M., \& Ahmadi, S. M. (2015). The effects of customer relationship management dimensions on organizational performance (Case study: shipping organization of Iran). WALIA journal, 31(4), 134-141.

Hair, B, Babin, A, \& Ta tham (Eds.). (2006). Multivariate data analysis. Upper Saddle River, N.J: Pearson Prentice Hall.

Hayes, A. F. (2013). Introduction to Mediation, Moderation and Conditional Process Analysis. New York: The Guilford Press.

Heinrich, B. (2005). Transforming strategic goals of CRM into process goals and activities. Business Process Management Journal, 11(6), 709-723.

Homburg, Christian, John P. Workman, \& Ove Jensen. (2000). Fundamental changes in marketing organization: the movement toward a customer-focused organizational structure. Journal of the Academy of Marketing Science, 28 (4), 459-478.

Jain, D., \& Singh, S. S. (2002). Customer lifetime value research in marketing: A review and future directions. Journal of interactive marketing, 16(2), 34.

Kaplan, R. S., \& Norton, D. P. (1996). Using the balanced scorecard as a strategic management system. Harvard Business Review, 75-85.

Karakostas, B., Kardaras, D., \& Papathanassiou, E. (2005). The state of CRM adoption by the financial services in the UK: an empirical investigation. Information \& Management, 42(6), 853-863.

Khan, A. I., \& Uddinl, A. N. M. (2010). Selection of cellular operators in Bangladesh: An empirical analysis. International Journal of Mobile Marketing, 5(2), 114-125.

Kim, M. K., Park, M. C., \& Jeong, D. H. (2004). The effects of customer satisfaction and switching barrier on customer loyalty in Korean mobile telecommunication services. Telecommunications policy, 28(2), 145-159.

Kotler, P. (2003). Marketing insights from A to Z: 80 concepts every manager needs. New Jersey: john wiley \& sons, Inc., hoboken.

Leelakulthanit, O., \& Hongcharu, B. (2011). Factors that impact customer satisfaction: Evidence from the Thailand mobile cellular network industry. International Journal of Management and Marketing Research, 4(2), 67-76.

Masroujeh, W, F. (2009).Critical factors for customer satisfaction and delight in the Palestinian pharmaceutical market. MBA Thesis, Islamic University of Gaza, Palestine.

Mohammed, A. Rashid, B. \& Shaharuddin, T. (2013). Assessing the influence of customer relationship management (CRM) dimensions on organization performance: An empirical study in the hotel industry. Journal of Hospitality and Tourism Technology, 4 (3), 228- 247.

Oyeniyi, O., \& Abiodun, A. J. (2011). Service Quality, Value Offer, Satisfaction and Loyalty: an Empirical Relationship in the Nigerian Telecom Industry. Journal of Contemporary Management Research, 5(2).

Peppard, Joe. (2000). Customer relationship management (CRM) in financial services. European Management Journal, 18 (3), 312-327.

Rahman, S., Haque, A., \& Ahmad, M. I. S. (2011). Choice criteria for mobile telecom operator: Empirical investigation among Malaysian customers. International Management Review, 7(1), 50.

Rahman, S., Haque, A., \& Ahmad, M. I. S. (2011). Choice criteria for mobile telecom operator: Empirical investigation among Malaysian customers. International Management Review, 7(1), 50. 
Randaccio, L. S. (2007). Resources optimization in multimedia communications. University of Cagliari, department of electrical and electronic engineering.

Ryals, L., \& Knox, S. (2001). Cross-functional issues in the implementation of relationship marketing through customer relationship management. European management journal, 19(5), 534-542.

Rygielski, C., Wang, J. C., \& Yen, D. C. (2002). Data mining techniques for customer relationship management. Technology in society, 24(4), 483-502.

Sadia, J., Tasneem, F., \& Khan, M. (2011). An empirical analysis of customer loyalty in Pakistan's telecommunication industry. Journal of Database Marketing \& Customer Strategy Management, 18(1), 5-15.

Schmid, J., \& Weber, A. (1998). Desktop database marketing. McGraw-Hill, Inc.

Sekaran (2003). Research methods for business: A skill-building approach. New York: JohnWiley and Sons.

Shafique.M, Haider.N, Hussain, A. (2015). Impact of customer relationship management capabilities on organizational performance with CRM technology as mediator. Arabian Journal of Business and Management Review, 4(10), 30.

Sheth, Jagdish N. (2002). The future of relationship marketing. Journal of Services Marketing, $16(7), 590-592$.

Simon, Dantzig, Hogarth, Plott, Raiffa, Schelling, et al. (1987). Decision Making and Problem Solving. Interfaces, 17(5).

Vandermerwe, S. (2004). Achieving deep customer focus. MIT Sloan Management Review, 45 (3), 26-34.

Vrechopoulos, Adam P. (2004). Mass customization challenges in internet retailing through information management. International Journal of Information Management, 2(4), 5971.

Widmier, Scott M., Donald W. Jackson, \& Deborah B. Mccabe. (2002). Infusing technology into personal selling. Journal of Personal Selling \& Sales Management, 22(3), 189198.

Wong, Ken Kwong-Kay (2010). Fighting churn with rate plan right-sizing: A customer retention strategy for the wireless telecommunications industry. The Service Industries Journal, 30(13), 2261-2271.

Wu, S. I., \& Li, P. C. (2011). The relationships between CRM, RQ, and CLV based on different hotel preferences. International Journal of Hospitality Management, 30(2), 262-271.

Yim, H, F., Anderson, R. E., \& Swaminathan, S. (2005). Customer relationship management: Its dimensions and effect on customer outcomes. Journal of Personal Selling \& Sales Management, 24(4), 263-278. 